\title{
The Implementation of Lesson Study Using Discovery Learning Model and Students'Worksheet Based on Constructivism on Relations and Functions Material
}

\author{
Eko Andy Purnomo ${ }^{1}$, Eny Winaryati ${ }^{2}$, Fitria Fatichatul Hidayah ${ }^{3}$, Muhimmatul Ifadah ${ }^{4}$ \\ \{ekoandy@unimus.ac.id ${ }^{1}$,enywinaryati@unimus.ac.id ${ }^{2}$, fitriafatichatul@unimus.ac.id ${ }^{3}$, \\ muhimatul@unimus.ac.id ${ }^{4}$ \\ University of Muhammadiyah Semarang, Jalan Kedungmundu Raya no. 22 Semarang City, Central \\ Java, Indonesia ${ }^{1,2,3,4}$
}

\begin{abstract}
The mastery of material concepts is the most fundamental point in learning mathematics. Mastering the right concepts will make it easier to learn the next material, so it is needed the depth and well concepts mastery. Based on the results of observations and interviews at Muhammadiyah 9 Junior High School of Semarang, it can be concluded that the students' difficulties in relation and function material are: 1) students cannot distinguish between relations and functions, 2) Students have difficulty in giving examples of functions and non functions, 3) The implementing functions in solving problem. Responding to the existing problems, we need a learning model that can provide opportunities for students to find concepts independently. Learning models that can be applied to overcome problems are discovery learning model. In order to the application of discovery learning is more maximal, it is necessary to be assisted by constructivism-based worksheets. The purpose of implementing lesson study is to improve the understanding of the concept of relations and functions. This study used a qualitative approach collaborated with descriptive analysis method. ) defining functions, 3) explaining relation and function, 4) distinguishing between relations and functions, 5) giving examples of relations and functions. The results shown that there is an improvement on the ability of understanding concepts about relations and functions.
\end{abstract}

Keywords: Concepts Understanding, Constructivism, Discovery Learning, Lesson Study

\section{Introduction}

The mastery of material concepts is the most fundamental point in learning materials. Mastering the right concepts will make it easier to learn the next material. Conversely, if the mastery of a concept that is not mature will result in students' difficulties in understanding the next material. The understanding of concepts in learning is important because concepts are building block thinking and the basis for higher mental processes and are useful for formulating principles and generalizations [1]. So that concept strengthening is the most fundamental thing that a teacher must instill in his students. One of the materials that must be planted mature is material relations and functions.

The function material contains two materials, such as; describing and presenting functions in various representations namely words, tables, graphs, diagrams, equations, and 
resolving problems related to relations and functions by using various representations. The abilities to understand concepts which are needed in studying relations and functions materials are 1) defining relations, 2) defining functions, 3) explaining relation and function relations, 4) distinguishing between relations and functions, 5) giving examples of relations and functions. In studying the material the first concept that students must master is understanding, the nature of relations and functions. The second concept is the difference between relations and functions. If students understand the concept of relations and function concepts, students will more easily distinguish between relations (not functions) and functions. In addition, students can also provide examples of whether it is a function or not a function and can apply the material in daily life.

Based on the results of observations and interviews at Muhammadiyah 9 Junior High School Semarang, it can be concluded that students' difficulties in understanding relations and functions materials such as; 1). students cannot distinguish between relations and functions, 2). students have difficulty giving examples of functions and not functions, 3). Implementing functions in solving problems. The examples of students' difficulties when they are given a problem through a set of sequential pairs like the following example: if the relation $P=\{1,2$, $3,4,5\}$ to $\mathrm{Q}=\{1,2,3,4,5,6,7,8,9,10\}$ relation defined "half times" whether it is a function or not! Student difficulties determine whether the problem is a function or not because not all domains are paired with a domain.

In addition, students' difficulties occur because students are not given the freedom to find concepts and investigate their own definition of relations and functions, the differences between relations and functions so that the concepts of relations and functions do not really settle in students' thinking. The teacher only gives the concept of the function at a glance and gives an example and not an example but the meaning has not yet reached the student. Besides, students also do not work on exercises related to the functions material. So as to overcome learning problems by emphasizing contextual learning through complex activities $[2]$.

Responding to the existing problems, we need a learning model that can provide opportunities for students to find the concept of functions independently. Through the discovery of the functions concept independently it will be easier for students to remember and the concept will be more mature. In addition, there are differences in understanding concepts and scientific attitudes between students on Discovery Learning model with direct learning model [3]. Learning models that can be applied to overcome relations and functions problems are discovery learning models. This learning syntax a) using a scientific approach through observing, asking, trying, reasoning, and communicating while paying attention to student's characteristics, b) using science as a driving force for learning for all subjects, c) guiding students to find out, not notified (discovery learning), and d) emphasizing language skills as a means of communication, bearer of knowledge and logical, systematic, and creative thinking.

In directing the mindset of students, the teacher needs a tool that can directly direct the mindset while creating students' independence in learning and finding knowledge. In this case, Students' Worksheet plays an important role to guide students in finding new knowledge. This design is adapted to the characteristics of students as well as the relations and functions of eight grade. In order for the application of discovery learning to be more maximal it is necessary to be assisted by a Students' Worksheet based on constructivism. Constructivism is the foundation of thinking (philosophy) of contextual learning, namely that knowledge is built by humans little by little, the results of which are expanded through limited 
and not sudden contexts [4]. The implementation of constructivism principles can "educate" future human beings with appropriate skills and skills [5] and knowledge formation [6].

The discovery learning model assisted by constructivism-based student worksheet is applied using lesson study. Lesson Study is a model for improving the quality of learning through collaborative and ongoing learning studies based on the principles of collegiality and mutual learning, to build learning communities [7]. In addition to aiming at improving the quality of aiming lesson study preparing children's future for a better life [8] and improving the process and quality of learning [9]. The application of lesson study will provide meaningful experiences for students and teachers. Through this collaborative learning activity, there will be an in-depth analysis of students' activities and concept understanding. So that the lesson studies activities are very supportive of the achievement of learning objectives.

\section{Methodology}

This study used a qualitative approach with descriptive analysis method. Descriptive analysis method is a method that attempts to describe and interpret objects in reality [10]. Lesson Study activities have three stages of plan, do, and see through the application of discovery learning model assisted by constructivism. The focus of the Lesson Study aims to determine the conceptual ability of the eighth grade students' relations and functions. The instruments which are used were students' worksheets and students' observation sheets. The results obtained will be described to illustrate the implementation of the Lesson Study activity and find out how the students function. three stages, namely: planning stage (plan), implementation phase (do) which is often referred to as research lesson and reflection (see) stage or post-lesson activity [11]. For more details the lesson study activities can be seen in the picture below:

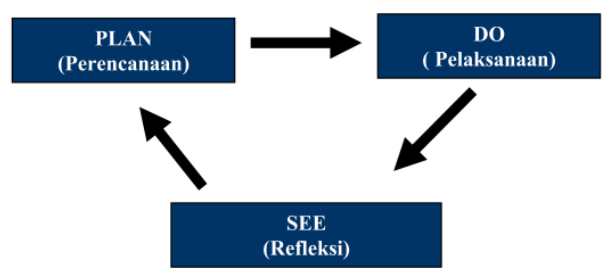

Figure 1. The stages of Implementing Lesson Study

\section{Results and Findings}

\subsection{Plan}

In this research, the learning activities used discovery learning models. The opening learning of students was given problems related to the function material. Submitting a problem as an activity in the classroom can facilitate students to think flexibly and assessed the results of their own work [12]. Through the problems given, the teacher determined the purpose of learning the function material. The next step, students were given constructivism-based $L K S$. This worksheet was designed so that students went through the simplest stage of mindset, namely the relationship to the complex stages, namely distinguishing relationships \& 
functions and knowing the reason. Through the concept of relations will be brought to the concept of functions. The hope was that with these stages students could easily find the concept of functions. $L K S$ activities can be seen in the picture below:

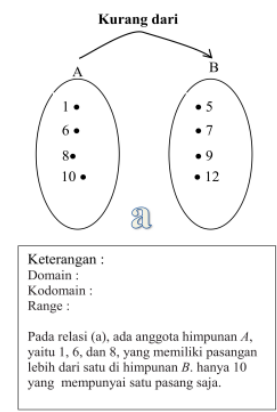

Figure 2. The Example of Materias in Students'Worksheet

In the first stage, the students were given a relationship "less than". At this initial stage students were asked to write domains, domains and ranges. After that students were asked to map domain A to codomain B. In the opening stages, students were still given guidance so students can solve the problem. Making the first question was still related to the relationship because there were several members of domain A had more than one partner in Kodomain B. Secondly, three and four students have been asked to solve the problem without the help of the teacher. Students were asked to solve problems according to the problems given. In solving problems, students had to put forward with the right answers. In answering the students were asked to work on the questions correctly and expressed the reasons correctly. Based on four questions given students were asked to conclude from the concept of a function as shown in the picture below. The functions conclusions there were 2 rules that must be found by students.

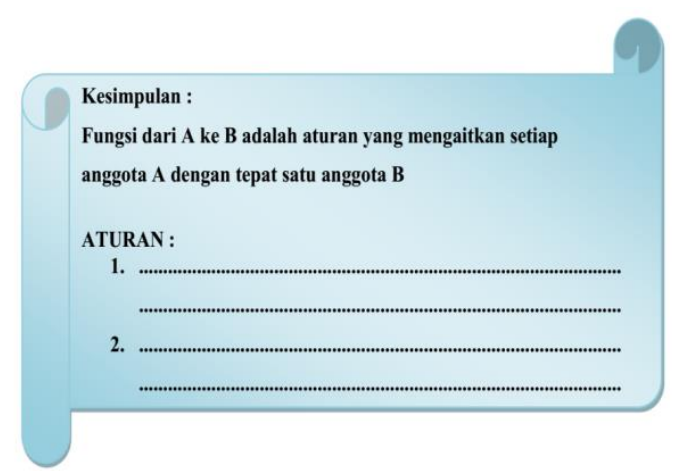

Figure 3. The Materials of Relations \& Functions Conclusion

After concluding the materials, the students were given evaluation questions. This evaluation question was divided into two parts, namely students were asked to work on whether it was a relations or functions and were asked to give reasons. Through this evaluation question, students were expected to be able to work correctly and put forward the reasons correctly. The evaluation questions are shown in the picture below. 
a.

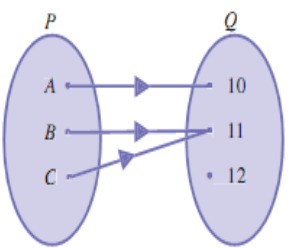

b.

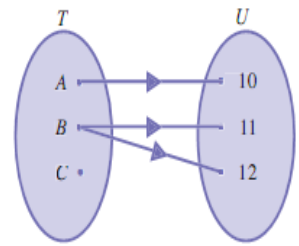

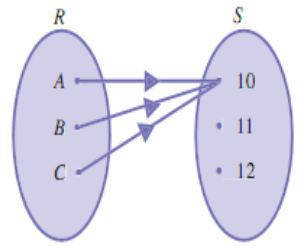

d.

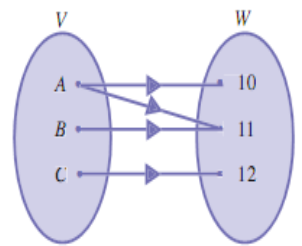

Figure 4 : The relations and functions evaluation questions

\subsection{Do}

The implementation of learning used discovery learning. In the opening stages, students were given problems related to everyday life. Students felt challenging with material linked with everyday life. In the opening stages, students were grouped with varied abilities. Problems were solved in groups, but each student had to write solutions to problems individually. They felt difficulties in solving problems, but by using teacher's guidance, they could solve existing problems. The learning activities can be seen in the picture below.

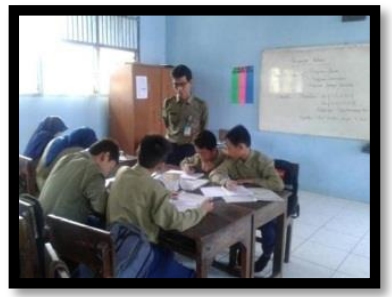

a

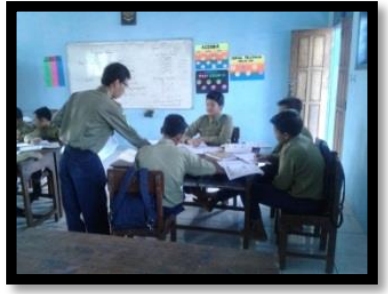

b

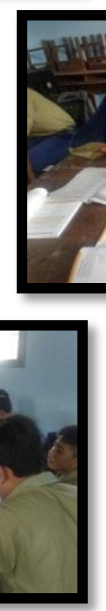

d

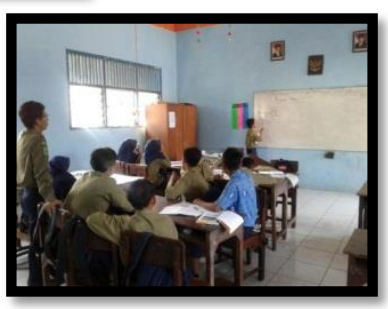

e

Figure 5. The lesson study implementation at SMP Muhammadiyah 9 
Discovery learning activities were designed by group learning activities. Through group discussions, student's activities increased. Students could discuss with each other regarding issues and material that had been given this can be seen in Figure 5.a although students had to complete assignments individually. The task was designed into two parts: group assignments and individual assignments. Group assignments were related to material understanding while individual tasks were related to the application of material. In figure 5.b. seen the teacher guided students in solving existing problems. The teacher carried out coaching and material reinforcement as well as checking students' concept understanding. Through this activity the teacher could see early on understanding the concept of the students so that if there were students who were wrong in understanding the concept the teacher could immediately knew and directed.

Students in group learning activities also helped each other to solve problems this can be seen in Figure 5.d. students who had understood the concept of teaching other students who had difficulties. This has 2 advantages, namely students who had not mastered the concept to be as knowledgeable as students who taught to be more understanding and deep understanding of the concept. After students solved problems students were asked to explain the results of group discussions as shown in Figure 5.e. Through providing opportunities to convey the results of the discussion students were more challenging and increased the courage of students. There were several groups that have different opinions. Each group expressed their opinions and discussed with each other.

\subsection{See}

The implementation of learning activities using discovery learning models worked well. This could be seen from the activity process and the results of students'discussion. The results of the assignment were stated in the students' worksheet and students' notebook. Worksheets were used for group assignments and students' notebooks as individual assignments. The students'worksheet results can be seen in the picture below

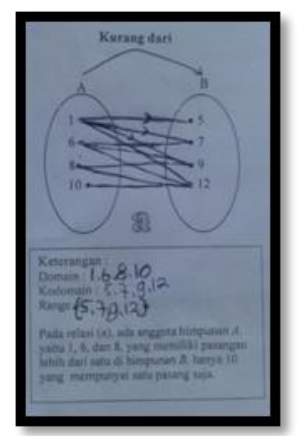

a

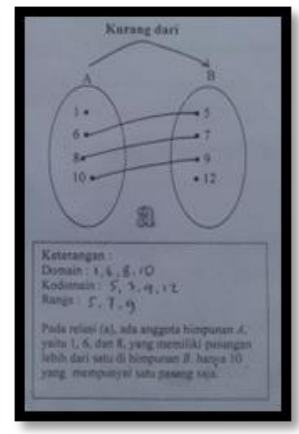

b

Figure 6. The students'result 
The implementation of learning activities using discovery learning models worked well. This ccould be seen from the activity process and the results of student discussion. The results of the assignment were stated in the student worksheet and student notebook. Worksheets were used for group assignments and student notebooks as individual assignments. Students! the student worksheet results could be seen in the picture below;

In Figure 6 the initial stages of the students were given problems with their guidance. In this relation all groups could determine domains and domains, but there were still those not finished correctly. In Figure 6.b students' understanding is wrong, in relation to "less than". One group resolved with its ordered pair $\{(6.5),(8.7),(10.9)\}$. Students thought upside down because students thought from domain to domain that is (5 less than 6$),(7$ is less than 8$)$, (9 is less than 10). This was a misconception of students who thought their partner was a domain to the domain even though the correct answer was in Figure 6.a. namely ( 1 less than 5), (1 less than 7), (1 less than 9), (1 less than 12) and so on. This concept error was immediately corrected by the teacher to overcome the next error. Through teacher's guidance, students' misconceptions could be overcome. From simple problems and the existence of guidance on student worksheet, students were then given more complex problems and without guidance on the student worksheet. The results can be seen in Figure 7 below.

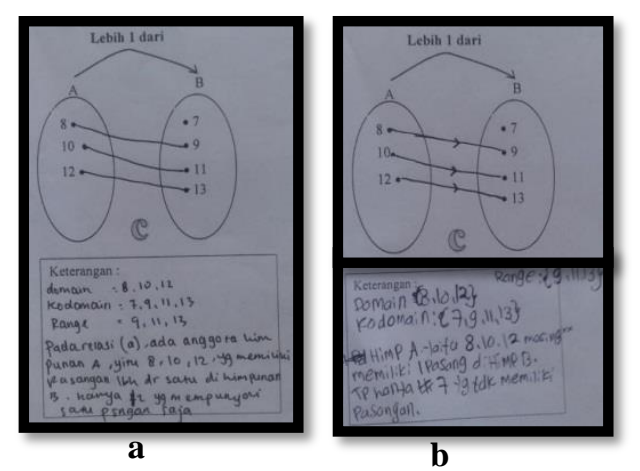

Figure 7. The Result of functions \& relations

In Figure 7 shows students had understood the domain, codomain and range material. All groups could also complete the relations correctly and could explain correctly. Domain (8, $10,12)$ codomain $(7,9,11,13)$ and range $(9,11,13)$ means that the understanding of the concept of relations had been mastered even though in Figure 7.a students were not precise in conveying it in narrative form. Conveying a narrative that was less precise was confirmed by the teacher so that the result of the concept of the relations could already be and in narrating it was correct. In the same problem students' understanding of functions was not yet deep. This can be seen in the picture below. In figure 7 students don't answer correctly. In figure 7 students think it is not a function assuming domain $\mathrm{A}$ is $8,10,12$ has 1 pair on the domain but $7 \mathrm{did}$ not have a partner. In the other groups the answer was correct that picture 7 was a function but the reason was incorrect because the reason wass the same as the previous group, domain A was 8, 10, 12 had 1 pair in the domain but 7 had no partner. This means that two groups has different answers but has the same reasons. This proves that the concept of function had not been understood in depth. The teacher anticipated the misconceptions that students assumed. The teacher emphasized that the function had two conditions, namely 1). each member of the domain had to be used up with a member of the domain but the domain 
did not have to be attached to all domains. 2). Domains might not form branches, but from two domain members might be paired in the same domain. These two conditions were stated in the conclusion of learning activities. To find out the understanding of the concept of relations and functions, the teacher gave evaluation questions. The problem in Figure 4 was used by the teacher to find out the level of understanding of students. The result of the evaluation students had understood and distinguished between functions or not functions and their reasons. Student evaluation can be seen in Figure 4 (evaluation of relation and function material) above.

In relation 4.a. students had understood correctly that it was a function even though in domain $\mathrm{P}$ there were members $\mathrm{B}$ and $\mathrm{C}$ who had the same partner in $\mathrm{Q}$ that was 10 . In relation 4.b students already knew that it was not a function because there was a domain $\mathrm{T}$ that was $\mathrm{B}$ had a branch (had two pairs namely $(\mathrm{B}, 11)$ and $(\mathrm{B}, 12)$ ). In relation 9.4 students had understood that function even though all domains had the same pair in kodomain that was 10 . In relation 4.d. not a function because on domain $\mathrm{V}$ that was $\mathrm{A}$ had more than one pair in the domain. Through several variations, the questions proved that the understanding of the concept of relations and functions was deep. In order to know more deeply the understanding of students' concepts, the teacher gave the task to provide examples of functions and not functions and their reasons. The results can be seen in Figure 8 below.

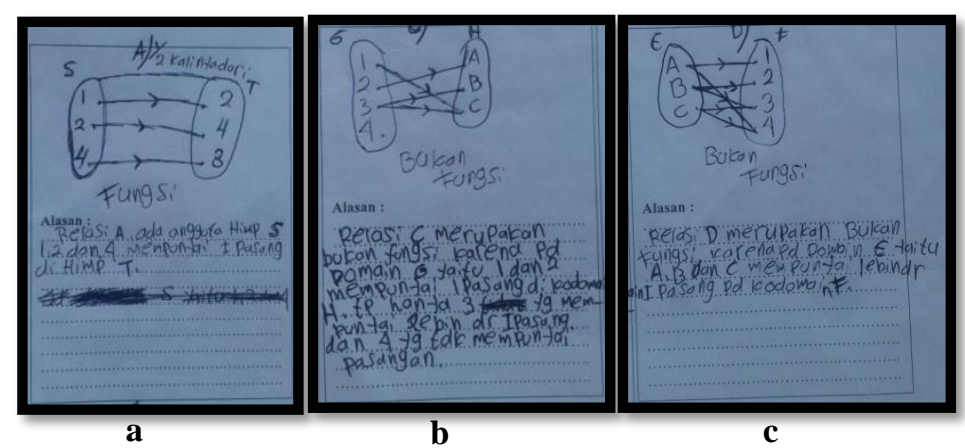

Figure 8. The Example of functions and not functions

In figure 8.a students gave a simple example of the function of this thing seen from the same domain and code and each domain was paired exactly one in the domain. Figure 8.b students gave examples not function correctly with the right reasons. On the domain there was a member that was three has two pairs in the domain that is $(3, \mathrm{~B})$ and $(3, \mathrm{C})$ and there were members of the domain that did not have a partner in the domain that was four. In figure 8.c students gave examples of all domains had two pairs in codomain. Based on the three examples given by students, this showed that students' conceptual understanding was correct.

\section{Discussion}

The understanding of the students in relations and functions was correct and profound. This was due to the application of the discovery learning model applied by the teacher. In this model, students were given the opportunity to observe by linking matter with everyday life. Then students were given the opportunity to ask questions, tried and reasons 
with facilitated constructivism-based $L K S$. Giving the opportunity to communicate the results of the camp discussion makes the students more active in accordance with [13] and which states that the learning model of Discovery Learning increased student's activity [14]. Through the stages of singing, reasoning and trying the understanding of the concept was also increasing, this is in line with which states the Discovery Learning model gave a big impact on the understanding of concepts.

Although constructivism-based students' worksheet were given the opportunity to explore their abilities and thinking power. $L K S$ is practical in nature can attract interest, as well as motivate learning [15] and improve learning outcomes [16]. Contructivism based worksheets gave students the opportunity to master the concept of relations material little by little, the results of which were extended to the concept of functions. In this case, indirectly students were guided by guidance from the teacher. This worksheet directed students 'mind patterns, could direct thinking patterns while creating students' independence in learning and finding knowledge. Based on these results, it could be concluded that the implementation of lesson study had been successful in improving the understanding of the concept of relations and functions material.

Through constructivism-based worksheets' students were given the opportunity to explore their abilities and thinking power. $L K S$ is practical in nature can attract interest, as well as motivate learning [15] and improve learning outcomes [16]. Contructivism based worksheets gave students the opportunity to master the concept of relations material little by little, the results of which were extended to the concept of functions. In this case indirectly students were guided by guidance from the teacher. This worksheet directed students 'mind patterns, could direct thinking patterns while creating students' independence in learning and finding knowledge. Based on these results, it can be concluded that the implementation of lesson study has been successful in improving the understanding of the concept of relations and functions material.

\section{Conclusion}

1. Implementation of lesson study runs well and provides meaningful experiences for students and teachers.

2. The Implementation of Discovery learning model in Lesson Study assisted by constructivism-based worksheets can enhance students' understanding of material concepts of relations and functions.

\section{References}

[1] Dahar R.W., 2006. Teori- teori Belajar. Cetakan ke-2. Bandung: Erlangga

[2] Purnomo, E.A, Rohman, A \& Budiharto, 2015. Efektivitas Penerapan Model Pembelajaran Project Based Learning (PBL) Berbasis Maple Matakuliah Kalkulus Lanjut II. Jurnal Karya Pendidikan $\quad$ Matematika. 20 (2) 24. https://jurnal.unimus.ac.id/index.php/JPMat/article/view/1700/1749

[3] Widiadnyana, I. W., Sadia, I. W., \& Suastra, I. W. (2014). Pengaruh Model Discovery Learning terhadap Pemahaman Konsep IPA dan Sikap Ilmiah Siswa SMP. Jurnal Pendidikan IPA, 4(1).

[4] Nurhadi, dkk. (2004). Pembelajaran Konstektual dan Penerapannya dalam KBK. Malang: Universitas Negeri Malang.

[5] Barlia, Lily. 2011. Kontruktivisme Dalam Pembelajaran Sains Di SD: Tinjauan Epistemologi, Ontologi, Dan Keraguan Dalam Praksisnya. Jurnal Cakrawala Pendidikan. Universitas Pendidikan Indonesia. No. XXX. Volume 3. Hal. 343- 358 
[6] Budiningsih, C. Asri. 2005. Belajar dan Pembelajaran. Rineka Cipta. Jakarta.

[7] Lewis, Catherine C, 2002, Lesson Study : A Handbook of Teacher-Led Instructional Change, Philadelphia, PA : research for better Schools,Inc.

[8] Supriatna, Asep (2014). "Etika dan Profesionalisme Pendidik utuk Pendidikan Karakter dalam Implementasi Kurikulum 2013”. Makalah disajikan dalam Seminar Nasional Pendidikan Karakter di Palopo tanggal 3 Mei 2014

[9] Purnomo, E.A. 2017. Implementasi Lesson Study untuk Meningkatkan Kualitas Pembelajaran pada Matakuliah Kalkulus Multivariabel. https://jurnal.unimus.ac.id/index.php/psn12012010/article/view/2970/2891

[10] Creswell. (2010). Research Design: pendidikan kualitatif, kuantitatif, dan mixed. Yogyakarta: Pustaka Pelajar

[11] Kadarisman. (2009). Teknik Dokumentasi dan Analisis Rekaman Video untuk Refleksi dalam Lesson Study. Makalah Deseminasi Lesson Study UNY diselenggarakan dalam rangka sosialisasi Lesson Study di Fakultas Lingkungan UNY.

[12] Kilic, Cigdem. 2013. Turkish Primary School Teachers" Opinion about Problem Posing Applications: Students, The Mathematics Curriculum and Mathematics Textbooks. Turkey: Mersin University

[13] Jalil, M. (2016). Pengembangan Pembelajaran Model Discovery Learning Berbantuan Tips Powerpoint Interaktif pada Materi Interaksi Makhluk Hidup Dengan Lingkungan. Refleksi edukatika, 6(2).

[14] Wahjudi, E. (2015). Penerapan Discovery Learning dalam Pembelajaran IPA Sebagai Upaya untuk Meningkatkan Hasil Belajar Siswa Kelas IX-I di SMP Negeri 1 Kalianget. LENSA (Lentera Sains): Jurnal Pendidikan IPA, 5(1).

[15] Uno, Hamzah B. 2008. Perencanaan Pembelajaran. Jakarta: Bumi Aksara

[16] Garfield, J. 2006. Exploring the Impact of Lesson Study on Developing Effective Statistic Curriculum. (online) : www.stat.uackland.ac.nz/-iase/publication/-11/Garfield.doc. 